\title{
Body mass index is associated with low postoperative cardiac output in patients undergoing aortic valve replacement
}

\section{El índice de masa corporal se asocia a bajo gasto cardiaco postoperatorio de pacientes sometidos a reemplazo valvular aórtico}

\author{
Nydia Avila-Vanzzini ${ }^{1 *}$, Enrique Berrios-Barcenas ${ }^{1}$, Jorge Cossio-Aranda ${ }^{1}$, Hector Herrera-Bello², \\ Laura L. Rodriguez-Chavez ${ }^{1}$, Nidia M. Briseño-Diaz, and Jorge Gaspar-Hernandez ${ }^{4}$
}

${ }^{1}$ Department of Out-Patient Care, Instituto National Institute of Cardiology Ignacio Chavez, Mexico City; ${ }^{2}$ Fundación Clinical Medica Sur, Mexico City; ${ }^{3}$ Autonomous University of Nayarit, Nayarit; ${ }^{4}$ Department of General Direction, National Institute of Cardiology Ignacio Chavez, Mexico City, Mexico

\begin{abstract}
Background: Overweight and obesity $(\mathrm{O} / \mathrm{O})$ generate lipotoxicity of the cardiac fiber and increase the incidence and progression of aortic valve stenosis. The low cardiac output syndrome (LCOS) is a timing complication after to aortic valve replacement (AVR) surgery. Objective: The objective of the study was to investigate if body mass index (BMI) $\mathrm{kg} / \mathrm{m}^{2}$ is a risk factor associated with LCOS and mortality in the post-operative period of AVR. Methods: A historic cohort study was designed, including patients with severe aortic stenosis (SAS), who were subjected to AVR. Results: 152 patients were included, 45 (29.6\%), with normal weight (NW), 60 were overweight (39.5\%), and 47 obese (30.9\%). The prevalence of systemic hypertension (HT) was higher in O/O $(p<0.0001)$. Incidence of LCOS was $44.7 \%$, being more frequent in the O/O groups compared to the NW group, 43.3\%, 68.1\%, and $22.2 \%$, respectively, $(p<0.05$ in overweight and $p<0.0001$ in the obese). Assessing the presence or absence of $L C O S$ associated with BMI as a numerical variable, we found that women, HT, BMI, left ventricular mass, and valve size, were associated with $\operatorname{LCOS}(p<0.02, p<0.02, p<0.001, p<0.032$, and $p<0.045$, respectively). Mortality was higher in patients who had LCOS $(p<0.02)$. Multivariate model showed that BMI was an independent risk factor for LCOS (odds ratio [OR] 1.21 [95\% Cl 1.08-1.35], $p<0.001$ ). Conclusion: BMI is a risk factor associated to LCOS in the post-operative period of AVR in patients with SAS.
\end{abstract}

Key words: Body mass index. Low cardiac output syndrome. Aortic valve stenosis. Surgery. Risk factors.

\section{Resumen}

Antecedentes: El sobrepeso y la obesidad (O/O) generan lipotoxicidad de la fibra cardíaca y aumentan la incidencia y progresión de la estenosis de la válvula aórtica. El síndrome de bajo gasto cardíaco (SBGC) es una complicación postquirúrgica de la cirugía de reemplazo de válvula aórtica (RVA). Objetivo: Investigar si el índice de masa corporal $\mathrm{kg} / \mathrm{m}^{2}$ (IMC) es un factor de riesgo asociado con SBGC y mortalidad en el postoperatorio de RVA. Métodos: Se diseñó un estudio de cohorte histórico, que incluyó pacientes con estenosis aórtica importante (EAl), que fueron sometidos a RVA. Resultados: Se

Correspondence:

*Nydia Ávila-Vanzzini

E-mail: vazzny74@yahoo.com
Available online: $23-12-2020$

Arch Cardiol Mex. 2020;90(4):453-460
Date of acceptance: $17-06-2020$

DOI: 10.24875/ACME.M20000165 www.archivoscardiologia.com
article under the CC BY-NC-ND license (http://creativecommons.org/licenses/by-nc-nd/4.0/). 
incluyeron 152 pacientes, 45 (29.6\%), con peso normal (N), 60 tenían sobrepeso (39.5\%) y 47 obesos (30.9\%). La prevalencia de hipertensión sistémica (HT) fue mayor en O/O ( $p$ < 0.0001). La incidencia de SBGC fue del 44.7\%, siendo más frecuente en los grupos O/O en comparación con el grupo $N, 43.3 \%, 68.1 \%, 22.2 \%$ respectivamente, $(p<0.05$ en sobrepeso y $p<0.0001$ en obesos). Al evaluar la presencia o ausencia de SBGC asociado con el IMC como una variable numérica, encontramos que las mujeres, HT, IMC, masa ventricular izquierda y tamaño de la válvula, se asociaron con $S B G C(p<0.02$, $p<0.02, p<0.001, p<0.032, p<0.045$, respectivamente). La mortalidad fue mayor en pacientes con SBGC $(p<0.02)$. EI modelo multivariado mostró que el IMC fue un factor de riesgo independiente asociado a SBGC [OR 1.21 (IC 95\% 1.08-1.35), $p<0.001]$. Conclusión: El IMC es un factor de riesgo asociado a SBGC en el postoperatorio de RVA en pacientes con EAl.

Palabras clave: Índice de masa corporal. Síndrome de bajo gasto cardíaco. Estenosis de la válvula aórtica. Remplazo valvular aórtico. Morbi-mortalidad.

\section{Introduction}

Overweight and obesity $(\mathrm{O} / \mathrm{O})$ are defined as excessive accumulation of fat that can lead to hormonal, inflammatory, and metabolic interactions that adversely affect all organs and systems. In the heart, the accumulation of free and intermediate fatty acids causes "cardiac lipotoxicity," a phenomenon that implies an increase of $\beta$-oxidation and excessive reactive oxygen species production. The excess of adipocytes in the body and inside the myocardium generate an inflammatory environment due to exposure to inflammatory cytokines that in the heart is translated by the precipitation of apoptosis and fibrosis of the cardiomyocytes. When this toxic environment is perpetuated it leads to irreversible structural and functional damage of the cardiac fiber ${ }^{1,2}$. Large epidemiological studies have associated obesity with an increase in the incidence of heart failure, even doubling its risk ${ }^{3,4}$; additionally, $\mathrm{O} / \mathrm{O}$ and abdominal obesity increases the incidence of aortic valve stenosis ${ }^{5}$ and is also associated with the progression $^{6}$. In addition, both $\mathrm{O} / \mathrm{O}$ and aortic valve stenosis coexist, and combined they cause greater damage to the cardiac fiber, since, on the one hand, there is an increase in systolic stress that inevitably leads to hypertrophy and myocardial fibrosis and, on the other hand, cardiac fiber is also exposed to a toxic and inflammatory environment that also leads to apoptosis and fibrosis ${ }^{7,8}$. In a previous study, our group evaluated the characteristics of ventricular remodeling in myocardial biopsies, in patients whit $\mathrm{O} / \mathrm{O}$ and severe aortic stenosis (SAS); we observed that this association caused greater fibrosis and fat infiltration compared with the group of patients with SAS without $\mathrm{O} / \mathrm{O}^{9}$. This increased presence of fibrosis in patients with SAS and $\mathrm{O} / \mathrm{O}$ suggests that aortic valve replacement (AVR) surgery may be more at risk and one of the main complications that increase morbidity and mortality in the post-surgical period is the low cardiac output syndrome $(\text { LCOS })^{10}$. In cardiac surgery, several risk factors have been associated with LCOS ${ }^{11-17}$. On the other hand, the large study by Mariscalco et al. ${ }^{18}$ concluded that in cardiac surgery $\mathrm{O} / \mathrm{O}$ are even associated as a protective factor, except for obesity Grade 3; we think that given the double aggression in the myocardium produced by SAS and O/O, post-operative behavior could be different and confer greater risk in the development of LCOS, in comparison with the rest of cardiac surgeries; therefore, the objective of this study was to investigate whether $\mathrm{O} / \mathrm{O}$ is an associated risk factor for developing LCOS in patients with isolated SAS undergoing AVR.

\section{Methods}

A retrospective observational study of the analytic cohort was performed, which consecutively included all the patients with SAS who underwent surgery scheduled for AVR in a period from 2015 to 2016; the selection diagram is shown in figure 1. Demographic data of the patients, their comorbidities, as well as their intra and post-operative evolution during the first 30 days or until hospital discharge were collected. Patients with previous cardiac surgery, associated moderate or severe valvular lesions, functional class III/IV of the NYHA, emergency surgery, left ventricular ejection fraction $<50 \%$, need of revascularization, malnutrition (body mass index $[\mathrm{BMI}]<18.5 \mathrm{~kg} / \mathrm{m}^{2}$ ), pre-operative plasmatic hemoglobin concentration $<12$ and $<14 \mathrm{~g} / \mathrm{dL}$ in women and men, respectively ${ }^{19}$, lymphocytes $<2000$ cells $/ \mu \mathrm{L}$, serum creatinine $>1.4 \mathrm{mg} / \mathrm{dL}$ were excluded from the study. Patients in whom a cardioplegia was different from Custodiol ${ }^{\circledR}$ or those with surgical accidents and prosthetic mismatch (effective orifice area with continuous Doppler $\left.\leq 0.85 \mathrm{~cm}^{2} / \mathrm{m}^{2}\right)^{20}$ were also excluded from the study. None of our patients had right ventricular failure in this study. Finally, all the patients had cardiopulmonary bypass use. 
357 patients underwent cardiac surgery between 2015-2016

\section{Exclusion by preoperative history}

-Previous surgery= 14

-Other $\geq$ moderate valve disease $=37$

- Need for revascularization $=48$

\section{Exclusion by presurgical clinical conditions}

-FC NYHA III/IV =11

-Emergency surgery $=3$

-LVEF $<50 \%=25$

-Presurgical low levels of hemoglobin, lymphocytes, or poor nutrition $=27$

-Creatinine $>1.4 \mathrm{mg} / \mathrm{dl}=18$

Exclusion by conditions in the operating

\section{room or later}

-Surgical accidents $=7$

- another type of cardioplegia other than Custodiol $^{\circledR}=13$

-Prosthetic mismatch $=2$

152 patients retained for final analysis

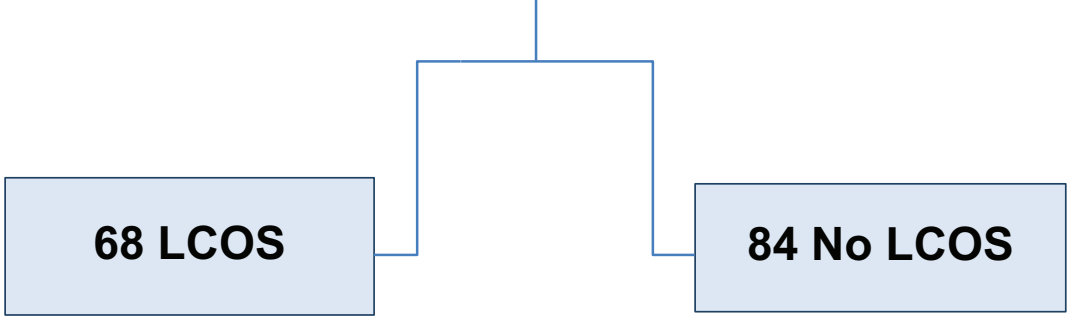

Figure 1. Patient selection. SAS: Severe aortic stenosis; FC NYHA: Functional Class of New York Hear Association; LVEF: left ventricular ejection fraction. 
Table 1. Demographic and echocardiography findings divided by groups

\begin{tabular}{|c|c|c|c|c|c|}
\hline & $\begin{array}{c}\text { Total, group } \\
\mathrm{n}=152\end{array}$ & $\begin{array}{l}\text { Normal weight }(29.6 \%) \\
\qquad \mathrm{n}=45\end{array}$ & $\begin{array}{l}\text { Overweight } \\
(39.5 \%) \mathrm{n}=60\end{array}$ & $\begin{array}{c}\text { Obesity } \\
(30.9 \%) \mathrm{n}=47\end{array}$ & $\mathbf{p}$ \\
\hline Age (years) & $67 \pm 10$ & $67 \pm 13$ & $67 \pm 10$ & $66 \pm 8$ & $0.747^{*}$ \\
\hline Male sex $(\%)$ & $82(53.9)$ & $25(55.6)$ & $37(61.7)$ & $20(42.6)$ & $0.205^{\wedge}$ \\
\hline Weight (kg) & $71 \pm 11$ & 62. \pm 9 & $71 \pm 9$ & $80 \pm 9$ & $<0.0001^{*}$ \\
\hline Height (mts) & $1.60(1.52-1.68)$ & $1.64(1.53-1.68)$ & $1.62(1.53-1.68)$ & $1.56(1.50-1.64)$ & $0.056^{+}$ \\
\hline BMI $\left(\mathrm{kg} / \mathrm{m}^{2}\right)$ & $27.7 \pm 3.7$ & $23.5 \pm 1.2$ & $27.7 \pm 1.0$ & $32.3 \pm 2.1$ & $<0.0001^{*}$ \\
\hline HT (\%) & $104(68.4)$ & $25(55.6)$ & $40(66.7)$ & $39(83)$ & $<0.0001^{\wedge}$ \\
\hline HT (Years of diagnosis) & $5.5(1-15)$ & $5(2-10)$ & $4.5(2-9)$ & $7(4-14)$ & $0.07^{+}$ \\
\hline $\begin{array}{l}\text { Treatment for SAH } \\
\text { ACE-I or ARA2 (\%) } \\
\text { BB (\%) } \\
\text { CC (\%) } \\
\text { Diuretic (\%) } \\
\text { ACE-I ARA2+diuretic (\%) } \\
\text { ACE-I o ARA2 + BB (\%) } \\
\text { Triple therapy (\%) } \\
\text { Without treatment (\%) }\end{array}$ & $\begin{array}{c}59(57) \\
8(7.6) \\
5(4.8) \\
1(0.9) \\
12(12) \\
8(7.6) \\
5(4.8) \\
6(5.7)\end{array}$ & $\begin{array}{c}15(60) \\
0 \\
1(4) \\
0 \\
2(8) \\
2(8) \\
3(12) \\
2(8)\end{array}$ & $\begin{array}{c}23(58) \\
4(10) \\
1(2.5) \\
1(2.5) \\
4(10) \\
3(5.0) \\
1(2.5) \\
3(7.5)\end{array}$ & $\begin{array}{c}21(54) \\
4(10.2) \\
3(7.6) \\
0 \\
6(15) \\
3(7.6) \\
1(2.5) \\
1(2.5)\end{array}$ & $0.91^{*}$ \\
\hline T2DM (\%) & $28(18)$ & $9(20)$ & $12(20)$ & $7(15)$ & $0.525^{\wedge}$ \\
\hline Smoking (\%) & $52(33)$ & $14(50)$ & $12(38)$ & $10(42)$ & $0.524^{\wedge}$ \\
\hline $\begin{array}{l}\text { Aortic valve diagnosis: } \\
\text { ISAS }(\%) \\
\text { MAVD }(\%)\end{array}$ & $\begin{array}{l}100(66) \\
52(34)\end{array}$ & $\begin{array}{l}26(58) \\
19(42)\end{array}$ & $\begin{array}{l}38(64) \\
22(37)\end{array}$ & $\begin{array}{l}36(77) \\
11(23)\end{array}$ & $0.057^{\wedge}$ \\
\hline Maximum gradient $(\mathrm{mmHg})$ & $92 \pm 21$ & $91 \pm 21$ & $92 \pm 18$ & $94 \pm 24$ & $0.903^{*}$ \\
\hline Mean gradient $(\mathrm{mmHg})$ & $57(45-71)$ & $58(44-65)$ & $55(47-70)$ & $57(41-74)$ & $0.953^{+}$ \\
\hline Aortic area $\left(\mathrm{cm}^{2}\right)$ & $0.6(0.5-0.7)$ & $0.6(0.5-0.7)$ & $0.6(0.5-0.8)$ & $0.6(0.5-07)$ & $0.742^{+}$ \\
\hline $\operatorname{LVEF}(\%)$ & $61(60-65)$ & $64(60-70)$ & $61(60-65)$ & $60(58-65)$ & $0.170^{+}$ \\
\hline $\begin{array}{l}\text { Diastolic dysfunction E/A (\%) } \\
\text { Grade } 1 \\
\text { Grade } 2 \\
\text { Grade } 3\end{array}$ & $\begin{array}{c}116(75) \\
31(20) \\
5(3.2)\end{array}$ & $\begin{array}{c}38(84) \\
5(11) \\
2(4.4)\end{array}$ & $\begin{array}{l}40(68) \\
17(28) \\
3(5.0)\end{array}$ & $\begin{array}{c}38(81) \\
9(19) \\
0\end{array}$ & $0.098^{\wedge}$ \\
\hline Left ventricular mass $\left(\mathrm{gr} / \mathrm{m}^{2}\right)$ & $126 \pm 17$ & $117.9 \pm 20$ & $128.7 \pm 15$ & $130.2 \pm 15$ & $<0.001^{*}$ \\
\hline Left atrial volume $\left(\mathrm{ml} / \mathrm{m}^{2}\right)$ & $32.8 \pm 5$ & $29 \pm 4$ & $32.5 \pm 5$ & $36.6 \pm 5$ & $<0.001^{*}$ \\
\hline SPP $(\mathrm{mmHg})$ & $27 \pm 8$ & $26 \pm 8$ & $30 \pm 8$ & $31 \pm 8$ & $<0.001^{*}$ \\
\hline
\end{tabular}

HT: systemic hypertension; BMI: body mass index; ACEl: angiotensin-converting enzyme inhibitor; ARA 2: angiotensin 2 receptor antagonist blocker; BB: beta-blocker; CC: calcium receptor antagonist; T2DM: type 2 diabetes mellitus; ISAS: isolated severe aortic stenosis; MAVD: mixed aortic valve disease (stenosis and regurgitation); LVEF: left ventricular ejection fraction; SPP: systolic pulmonary pressure. Comparison with one-way ANOVA test $(*)$, Kruskal-Wallis test $(+)$ and Lineal trend Chi-square $(\wedge)$.

LCOS was diagnosed if in intensive care unit, after correction of all abnormalities of electrolytes and blood gases and after adjusting the preload to its optimal value the patient required inotropic medication (dopamine, dobutamine, or epinephrine) to maintain systolic blood pressure by at least $90 \mathrm{mmHg}$ and cardiac output by $2.2 \mathrm{l} / \mathrm{min} / \mathrm{m}^{2}$ for $30 \mathrm{~min}$ or more ${ }^{21}$.

According to the $\mathrm{BMI} \mathrm{kg} / \mathrm{m}^{2}(\mathrm{BMI})$, the patients were divided into three groups: normal weight (NW) group
(NW, BMl between 18.5 and $<25 \mathrm{~kg} / \mathrm{m}^{2}$ ), overweight with BMI 25 and $<30 \mathrm{~kg} / \mathrm{m}^{2}$, and obese group with BMI of $30 \mathrm{~kg} / \mathrm{m}^{2}$ or more.

\section{Evaluation of echocardiograms}

The reports of two-dimensional transthoracic echocardiography performed on patients before AVR surgery were reviewed (all were performed at least 6 
Table 2. Surgical and post-surgical variables

\begin{tabular}{|c|c|c|c|c|c|}
\hline & $\begin{array}{c}\text { Total group } \\
n=152\end{array}$ & $\begin{array}{l}\text { Normal weight } \\
(29.6 \%) n=45\end{array}$ & $\begin{array}{c}\text { Overweight } \\
(39.5 \%) \mathrm{n}=60\end{array}$ & $\begin{array}{c}\text { Obesity } \\
(30.9 \%) \quad n=47\end{array}$ & $\mathbf{p}$ \\
\hline ECT (min) & $93(75-124)$ & $94(78-105)$ & $92(73-110)$ & $94(80-117)$ & $0.929^{+}$ \\
\hline ACT (min) & $68(52-87)$ & $69(55-84)$ & $67(55-79)$ & $68(55-80)$ & $0.805^{+}$ \\
\hline Prostheses size, (Diameter in $\mathrm{mm}$ ) & $21.5 \pm 1.6$ & $21.4 \pm 1.5$ & $21.5 \pm 1.7$ & $21.4 \pm 1.7$ & $0.944^{*}$ \\
\hline $\operatorname{BSA}\left(\mathrm{m}^{2}\right)$ & $1.77(1.67-1.88)$ & $1.77(1.65-1.91)$ & $1.79(1.70-1.87)$ & $1.78(1.67-1.85)$ & $0.872^{+}$ \\
\hline $\begin{array}{l}\text { Valve type (\%) } \\
\text { Mechanical } \\
\text { Bio-prostheses }\end{array}$ & $\begin{array}{l}67(44.1) \\
85(55.9)\end{array}$ & $\begin{array}{l}17(37.8) \\
28(62.2)\end{array}$ & $\begin{array}{l}28(46.7) \\
32(53.3)\end{array}$ & $\begin{array}{l}22(46.8) \\
25(53.2)\end{array}$ & $<0.001^{\wedge}$ \\
\hline Annular enlargement (\%) & $8(5.2)$ & $4(8.8)$ & $2(3.4)$ & $2(4.2)$ & $0.453^{\wedge}$ \\
\hline $\operatorname{CVP}\left(\mathrm{cmH}_{2} \mathrm{O}\right)$ & $11(9-14)$ & $10(9-12)$ & $11(9-14)$ & $12(11-15)$ & $0.019^{+}$ \\
\hline PCP $(\mathrm{mmHg})$ & $13 \pm 4$ & $10 \pm 5$ & $14.5 \pm 7$ & $16 \pm 5$ & $<0.0001^{*}$ \\
\hline Low cardiac output syndrome (\%) & 68 (44.7) & $10(22.2)$ & $26(43.3)$ & $32(68.1)$ & $<0.0001^{\wedge}$ \\
\hline
\end{tabular}

ECT: extracorporeal circulation time; ACT: aortic clamping time; BSA: body surface area; CVP: central venous pressure; PCP: pulmonary capillary pressure. Comparison with One-Way ANOVA test $\left({ }^{*}\right)$, Kruskal-Wallis test $(+)$ and Lineal trend Chi-square $(\wedge)$.

months before the surgical event). SAS was considered when an aortic transvalvular velocity $\geq 4 \mathrm{~m} / \mathrm{s}$ and mean gradient $\geq 40 \mathrm{mmHg}$ were detected by continuous Doppler. We also collected: left ventricular mass and ejection fraction, left atrium volume, systolic pulmonary pressure, diastolic function and gradients, velocities, and valve area. If in addition to SAS, there was regurgitation greater or equal to moderate, with vena contracta method of $4 \mathrm{~mm}$, and descending aortic reverse velocity $>15 \mathrm{~cm} / \mathrm{s}$, it was defined as mixed aortic valve disease. After surgery, prosthetic valve function was evaluated by transthoracic echocardiography in those cases with LCOS.

\section{Statistical analysis}

The categorical variables were summarized in frequency and proportions. The numerical variables are summarized as mean and standard deviation or median and $25^{\text {th }}$ and $75^{\text {th }}$ percentiles, according to their distribution. We performed a bivariate analysis with Student's T or ANOVA for the quantitative variables with normal distribution; Mann-Whitney U- or Kruskal-Wallis test was used for quantitative variables with non-parametric distribution, and Pearson's Chi-square test or linear trend for categorical variables. Univariate and multivariate analyses were performed with logistic regression to determine the predictors of LCOS. A value of two-tailed $p<0.05$ was considered as significant. All the analysis was performed with the statistical package SPSS version 21.

\section{Results}

152 patients were included in the study, $45(29.6 \%)$ had NW, 60 were overweight (39.5\%), and 47 obese (30.9\%); demographic and echocardiography findings are shown in Table 1. There were no differences in sex, age, history of type 2 diabetes mellitus, smoking, maximum and medium gradients, aortic valve area, left ventricular ejection fraction, or diastolic dysfunction. The prevalence of hypertension (HT) was higher in the O/O groups compared to the NW group: $66.7 \%, 83 \%$, and $55.6 \%$, respectively $p<0.0001$. On the other hand, left ventricular mass, left atrium volume, and systolic pulmonary pressure were higher in the $\mathrm{O} / \mathrm{O}$ compared to NW group, in all $p<0.001$.

Operative and post-surgical characteristics of the patients are shown in table 2; there were no differences in extracorporeal circulation time, aortic clamping time, or prosthetic valve size. Central venous pressure and pulmonary capillary pressure were higher in the O/O groups compared to NW patients, with $p<0.019$ and $<0.0001$, respectively. Global incidence of LCOS was $44.7 \%$, being more frequent in the $0 / 0$ groups compared to NW group: $43.3 \%, 68.1 \%$, and $22.2 \%$, respectively, $p<0.05$ in overweight and $p<0.0001$ in obesity. 
Table 3. Factors associated with LCOS

\begin{tabular}{|c|c|c|c|}
\hline & $\begin{array}{c}\text { No LCOS } \\
\mathrm{n}=84\end{array}$ & $\begin{array}{l}\text { LCOS } \\
n=68\end{array}$ & $\mathbf{p}$ \\
\hline Labeled valve size & $21.7 \pm 1.5$ & $21.1 \pm 1.7$ & $<0.045$ \\
\hline Age (years) & $65.8 \pm 10.4$ & $67.5 \pm 9.9$ & 0.290 \\
\hline BMI $\left(\mathrm{kg} / \mathrm{m}^{2}\right)$ & $26.5 \pm 3.2$ & $29.2 \pm 3.8$ & $<0.001$ \\
\hline Left atrial volume $\left(\mathrm{ml} / \mathrm{m}^{2}\right)$ & $32.2 \pm 5.4$ & $33.7 \pm 5.4$ & 0.087 \\
\hline Left ventricular mass $\left(\mathrm{grs} / \mathrm{m}^{2}\right)$ & $123 \pm 18$ & $129 \pm 16$ & $<0.032$ \\
\hline $\mathrm{SPP}(\mathrm{mmHg})$ & $29 \pm 9$ & $30 \pm 8$ & 0.673 \\
\hline Maximum gradient $(\mathrm{mmHg})$ & $93.1 \pm 20$ & $91.4 \pm 22$ & 0.712 \\
\hline Mean gradient $(\mathrm{mmHg})$ & $59 \pm 18$ & $53 \pm 21$ & 0.205 \\
\hline Aortic valve area $\mathrm{cm}^{2}$ & $0.64 \pm 0.1$ & $0.63 \pm 0.1$ & 0.700 \\
\hline $\operatorname{LVEF}(\%)$ & $63 \pm 7$ & $62 \pm 5$ & 0.281 \\
\hline ECT (min) & $68 \pm 17$ & $72 \pm 25$ & 0.518 \\
\hline ACT (min) & $93 \pm 25$ & $102 \pm 34$ & 0.124 \\
\hline Women (\%) & $30(36)$ & $40(59)$ & $<0.02$ \\
\hline HT (\%) & $49(58)$ & $55(81)$ & $<0.02$ \\
\hline T2DM (\%) & $14(17)$ & $14(21)$ & 0.137 \\
\hline Smoking (\%) & $34(41)$ & $18(26)$ & 0.056 \\
\hline $\begin{array}{l}\text { Diastolic dysfunction } \\
\text { Grade } 1(\%) \\
\text { Grade } 2(\%) \\
\text { Grade } 3(\%)\end{array}$ & $\begin{array}{l}62(74) \\
19(23) \\
3(4)\end{array}$ & $\begin{array}{l}54(79) \\
12(18) \\
2(3)\end{array}$ & 0.097 \\
\hline $\begin{array}{l}\text { Aortic valve diagnosis } \\
\text { ISAS (\%) } \\
\text { MAVD (\%) }\end{array}$ & $\begin{array}{l}53(63.1) \\
31(36.9)\end{array}$ & $\begin{array}{l}47(69.1) \\
21(30.9)\end{array}$ & 0.102 \\
\hline Mortality \% & $2(2.4)$ & $11(16.2)$ & $<0.02$ \\
\hline
\end{tabular}

BMI: body mass index; SPP: systolic pulmonary pressure; LVEF: left ventricular ejection fraction; ECT: extracorporeal circulation time; ACT: aortic clamping time; HT: systemic hypertension; T2DM: type 2 diabetes mellitus; ISAS: isolated severe aortic stenosis; MAVD: mixed aortic valve disease (stenosis and regurgitation).

Comparison with t-test and Chi-square test.

We also assessed the effect of $\mathrm{BMI}$ and the presence or absence of LCOS with the former analyzed as continuous numerical variable; in this setting, we found that the female sex, $\mathrm{HT}, \mathrm{BMI} \mathrm{Kg} / \mathrm{m}^{2}$, left ventricular mass, and the labeled valve size were associated with LCOS, $p<0.02, p<0.02, p<0.001, p<0.032$, and $p<0.045$, respectively. Mortality was higher in patients who developed LCOS, $p<0.02$ (Table 3). The identified causes of death were cardiogenic shock (six patients, 46.1\%); septic shock (six patients, $46.1 \%$ ), and one patient had mixed shock (septic and cardiogenic, 7.69\%).
About $84.6 \%$ of the deaths occurred in patients with $\mathrm{O} / \mathrm{O}$, and $15.3 \%$ were in NW.

Bivariate analysis by logistic regression showed that female sex (odds ratio [OR] 2.57 [95\% confidence interval (Cl) 1.33-4.96], p < 0.005), HT (OR $3.02[95 \% \mathrm{Cl}$ 1.43-6.35], $\mathrm{p}<0.004)$, BMI (OR 1.23 [95\% Cl 1.12-1.36], $p<0.001)$, left ventricular mass (OR: $1.02[95 \% \mathrm{Cl} 1.00$ 1.04], $p<0.03)$, and the labeled valve size of the prosthesis (OR 0.81 [95\% Cl 0.66-0.99], $p<0.04$ ) were factors associated with LCOS (Table 4). The multivariate model showed that only BMI was an independent risk factor to develop LCOS (OR 1.21 [95\% Cl 1.08-1.35], $p<0.001$ ) (Table 4).

\section{Discussion}

This study shows that in patients with SAS, a high $\mathrm{BMI}$, are a risk factor associated with LCOS in the post-operative period of $A V R$, increasing the risk by $21 \%$ for each BMI unit above $25 \mathrm{~kg} / \mathrm{m}^{2}$. LCOS is a serious complication following cardiac surgery ${ }^{22}$. In our study, LCOS was associated with a $16.2 \%$ death rate, compared to $2.4 \%$ in patients who did not develop this syndrome, $p<0.02$. Several predictive factors for LCOS have been studied ${ }^{10,23,24}$ but little attention has been given to $\mathrm{O} / \mathrm{O}$ as predictors. To answer this question, we eliminated from the analysis patients with confounding variables (those already recognized as risk factor for LCOS), except for diabetes and HT, the latter, due to its frequent association with aortic stenosis. In the present study, all the patients had normal baseline left ventricular ejection fraction; however, with this apparently favorable scenario, the overall incidence of LCOS was $44.7 \%$. We then analyzed the pre-existing and the intermediate variables that could correlate with this high incidence, such as aortic clamping time, extracorporeal circulation time or left ventricular mass (due to the probability of differences for myocardial preservation during the time of ischemia), and without identifying statistic differences. In a previous report in which our group studied similar groups of patients with SAS; we found an incidence LCOS of $41 \%^{25}$. In the literature, there are reports of other investigations that show a wide range of incidence of LCOS being between 3 and $45 \%^{10-26}$; we think that this wide incidence is consequence of different criteria used to diagnose it.

Regarding HT, Lund et al. ${ }^{27}$ reported that the prevalence in patients with aortic stenosis increased with increasing BMI, being of $63 \%$ in their obesity group. We found a global prevalence of $68.4 \%$, and $83 \%$ in the obesity group. The difference with Lund's study is that 
Table 4. Bivariate and multivariate analysis to evaluate the association with LCOS

\begin{tabular}{|l|c|c|c|c|}
\hline Variable & Bivariate OR (CI 95\%) & p & Multivariate OR (CI 95\%) & P \\
\hline Female sex & $2.57(1.33-4.96)$ & 0.005 & $2.07(0.96-4.45)$ & 0.06 \\
\hline HT & $3.02(1.43-6.35)$ & 0.004 & $2.08(0.93-4.66)$ & 0.07 \\
\hline BMI $\left(\mathrm{Kg} / \mathrm{m}^{2}\right)$ & $1.23(1.12-1.36)$ & $<0.001$ & $1.21(1.08-1.35)$ & $<0.001$ \\
\hline Left ventricular mass $\left(\mathrm{grs} / \mathrm{m}^{2}\right)$ & $1.02(1.00-1.04)$ & 0.03 & $1.01(0.99-1.03)$ & 0.31 \\
\hline Labeled valve size & $0.81(0.66-0.99)$ & 0.04 & $0.84(0.66-1.07)$ & 0.16 \\
\hline
\end{tabular}

OR: odds ratio; $\mathrm{Cl}$ : confidence interval; $\mathrm{HT}$ : systemic hypertension; BMI: body mass index.

they only included patients with mild-to-moderate aortic stenosis, while in our study all the patients had SAS. However, our study agrees with the Lund's study ${ }^{27}$ in associating BMI with a higher prevalence of $\mathrm{HT}$ in the context of aortic stenosis.

Myocardial hypertrophy is a known risk factor for $\mathrm{LCOS}^{28}$, as HT and SAS have been causes associated with greater hypertrophy, this could predispose to inadequate myocardial preservation. We analyzed whether left ventricular hypertrophy alone was associated with LCOS; however, the multivariate model did not show statistical significance. In another similar study, the authors also did not find that $\mathrm{HT}$ was associated with the syndrome ${ }^{10}$.

Regarding the size of the implanted prosthesis, the mean in this study was $21.5 \pm 1.6 \mathrm{~mm}$, without statistical difference between groups $(p=0.94)$. A method to calculate the prosthesis to be placed, is to use the body surface area $\mathrm{m}^{2}\left(B S A \mathrm{~m}^{2}\right)^{29}$, with this value, investigators ${ }^{30}$ showed that their group of SAS, had BSA higher than that observed in our population (2.06 vs. $1.77 \mathrm{~m}^{2}$, respectively), which can explain the smaller valve size in our population. Finally, we also analyzed the relationship between prosthetic valve size, BMI, and the presence of LCOS using multivariate analysis, and we did not find that valve size was an independent risk factor associated with LCOS. Maganti et al. ${ }^{10}$ found that a small size of the prosthesis emerges as a predictor of mortality with OR 1.3; however, it is not a predictor of LCOS as such.

We observed that the patients who developed LCOS had higher mortality at 30 -days, which was $16.2 \%$ versus $2.4 \%$ in the group that did not develop LCOS $(p<0.02)$. The previous studies have associated LCOS with morbidity and mortality ${ }^{10}$. Interestingly the Mariscalco's study ${ }^{18}$ found that obesity is associated with a low risk of mortality after cardiac surgery. Although this is a large study, which included 13 countries, it has several differences that make it not comparable with our population: first of all, that study includes patients one decade younger: 59 (18-67) years versus $67 \pm 10$ (6074) years, respectively, second, $27 \%$ were women, while in our group women comprised $47.1 \%$ of the population; in third place, Mariscalco's study included all cardiac surgeries, the vast majority of which were coronary artery bypass surgery, but even lower risk procedures were included, such as right mini-thoracotomy for the mitral valve and trans-AVR, in their logistic regression analysis only Grade 3 obesity was associated as an independent risk factor for mortality following isolated valvular surgery, [OR $1.26(\mathrm{Cl} 95 \%$ 1.01-1.58) $\mathrm{p}<$ 0.041 ], but not only were patients with SAS and AVR as in our group, in fact, valve surgery in general formed a low percentage of the total of their patients. For all the above, the result of supporting the paradox of obesity should be taken with reserve, this may apply to certain groups and ages, as our study which focused on patients with SAS and AVR, the results were different.

\section{Clinical implications}

LCOS is a dreaded complication of cardiac surgery, which increases morbidity and mortality. Other factors have been associated to its presentation, but the $\mathrm{O} / \mathrm{O}$ has been little studied, in fact, there has been controversy between whether or not it is a risk factor. In our SAS group, it turned out to be a predictor for the development of LCOS and we consider that it is of vital importance to recognize them, as a risk factor to be able to use strategies that decrease their incidence, prospective studies will be necessary to confirm these observations.

\section{Conclusion}

$\mathrm{BMI}$ is a risk factor associated with LCOS in the post-operative period of AVR in patients with SAS, 
increasing the risk by $21 \%$ for each unit of BMl above $25 \mathrm{~kg} / \mathrm{m}^{2}$. LCOS is a serious complication that increases the risk of death.

\section{Conflicts of interest}

None.

\section{Funding}

This research has not received any specific grant from public, commercial, or non-profit agencies.

\section{Ethical disclosures}

Protection of human and animal subjects. The authors declare that no experiments were performed on humans or animals for this study.

Confidentiality of data. The authors declare that they have followed the protocols of their work center on the publication of patient data.

Right to privacy and informed consent. The authors declare that no patient data appear in this article.

\section{References}

1. Nishida K, Otsu K. Inflammation and metabolic cardiomyopathy. Cardiovasc Res. 2017;113:389-98.

2. Zlobine I, Gopal K, Ussher JR. Lipotoxicity in obesity and diabetes-related cardiac dysfunction. Biochim Biophys Acta. 2016;1860:1555-68.

3. Kenchaiah S, Evans JC, Levy D, Wilson PW, Benjamin EJ, Larson MG et al. Obesity and the risk of heart failure. N Engl J Med. 2002:347:305-13

4. Loehr LR, Rosamond WD, Poole C, McNeill AM, Chang PP, Folsom AR, et al. Association of multiple anthropometrics of overweight and obesity with incident heart failure: the atherosclerosis risk in communities study. Circ Heart Fail. 2009;2:18-24.

5. Larsson SC, Wolk A, Håkansson N, Bäck M. Overall and abdominal obesity and incident aortic valve stenosis: two prospective cohort studies. Eur Heart J. 2017;38:2192-7.

6. Sengeløv M, Cheng S, Biering-Sørensen T, Matsushita K, Konety S, Solomon SD, et al. Ideal cardiovascular health and the prevalence and severity of aortic stenosis in elderly patients. J Am Heart Assoc. 2018;7:e007234.

7. Mahmod M, Bull S, Suttie JJ, Pal N, Holloway C, Dass S, et al. Myocardial steatosis and left ventricular contractile dysfunction in patients with severe aortic stenosis. Circ Cardiovasc Imaging. 2013;6:808-16.

8. Kupari M, Turto H, Lommi J. Left ventricular hypertrophy in aortic valve stenosis: preventive or promotive of systolic dysfunction and heart failure? Eur Heart J. 2005;26:1790-6.

9. Ávila-Vanzzini N, Fritche-Salazar JF, Vázquez-Castro NM, Rivera-Lara P, Pérez-Méndez $\mathrm{O}$, Martínez-Herrera $\mathrm{H}$, et al. Echocardiographic and histologic correlations in patients with severe aortic stenosis: influence of overweight and obesity. J Cardiovasc Ultrasound. 2016;24:303-11.

10. Maganti MD, Vivek R, Borger MA, Ivanov J, David TE. Predictor of low cardiac output after isolated aortic valve surgery. Circulation. 2005;112:1448-52.
11. Ding W, Ji Q, Shi $Y$, Ma R. Predictors of low cardiac output syndrome after isolated coronary artery bypass grafting. Int Heart J. 2015;56:144-9.

12. Sá MP, Nogueira JR, Ferraz PE, Figueiredo OJ, Cavalcante WC, Cavalcante TC, et al. Risk factors for low cardiac output syndrome after coronary artery bypass grafting surgery. Rev Bras Cir Cardiovasc. 2012;27:217-23.

13. Pan W, Hindler K, Lee VV, Vaughn WK, Collard CD. Obesity in diabetic patients undergoing coronary artery bypass graft surgery is associated with increased postoperative morbidity. Anesthesiology. 2006;104:441-7.

14. Tolpin DA, Collard CD, Lee VV, Elayda MA, Pan W. Obesity is associated with increased morbidity after coronary artery bypass graft surgery in patients with renal insufficiency. J Thorac Cardiovasc Surg. 2009:138:873-9.

15. Lomivorotov VV, Efremov SM, Boboshko VA, Nikolaev DA, Vedernikov PE, Deryagin MN, et al. Prognostic value of nutritional screening tools for patients scheduled for cardiac surgery. Interact Cardiovasc Thorac Surg. 2013;16:612-8.

16. Hernández-Leiva E, Dennis R, Isaza D, Umaña JP. Hemoglobin and B-type natriuretic peptide preoperative values but not inflammatory markers, are associated with postoperative morbidity in cardiac surgery: a prospective cohort analytic study. J Cardiothorac Surg. 2013;8:170.

17. Lomivorotov VV, Efremov SM, Boboshko VA, Leyderman IN, Lomivorotov VN, Cheung AT, et al. Preoperative total lymphocyte count in peripheral blood as a predictor of poor outcome in adult cardiac surgery. J Cardiothorac Vasc Anesth. 2011;25:975-80.

18. Mariscalco G, Wozniak MJ, Dawson AG, Serraino GF, Porter R, Nath M, et al. Body mass index and mortality among adults undergoing cardiac surgery: a nationwide study with a systematic review and meta-analysis. Circulation. 2017:135:850-63.

19. Díaz PP, Olay FG, Hernández RH, Cervantes-Villagrana RD, Presno-Bernal JM, Alcántara GL. Determinación de los intervalos de referencia de biometría hemática en población mexicana. Rev Mex Patol Clin Med Lab. 2012;59:243-50.

20. Domoto S, Niinami H, Uwabe K, Koike H, Tabata M, Morita K, et al. Comparison of early haemodynamics of $19-\mathrm{mm}$ aortic valve bioprostheses in patients with a small aortic annulus. Interact Cardiovasc Thorac Surg. 2016;22:19-25

21. Weisel RD, Burns RJ, Baird RJ, Hilton JD, Ivanov J, Mickle DA, et al. Optimal postoperative volume loading. J Thorac Cardiovasc Surg. 1983;85:552-63

22. Lomivorotov VV, Efremov SM, Kirov MY, Fominskiy EV, Karaskov AM. Low-cardiac-output syndrome after cardiac surgery. J Cardiothorac Vasc Anesth. 2017:31:291-308.

23. Hamad MA, van Straten AH, Schönberger JP, ter Woorst JF, de Wolf AM, Martens EJ, et al. Preoperative ejection fraction as a predictor of survival after coronary artery bypass grafting: comparison with a matched general population. J Cardiothorac Surg. 2010;5:29.

24. Cuthbertson BH, Croal BL, Rae D, Gibson PH, McNeilly JD, Jeffrey RR, et al. N-terminal pro-B-type natriuretic peptide level sand early outcome after cardiac surgery: a prospective cohort study. $\mathrm{Br} \mathrm{J}$ Anaesth. 2009;103:647-53.

25. Balderas-Muñoz K, Rodríguez-Zanella H, Fritche-Salazar JF, Ávila-Vanzzini N, Juárez Orozco LE, Arias-Godínez JA, et al. Improving risk assessment for post-surgical low cardiac output syndrome in patients without severely reduced ejection fraction undergoing open aortic valve replacement. The role of global longitudinal strain and right ventricular free wall strain. Int J Cardiovasc Imaging. 2017;33:1483-9.

26. Vela JL, Benítez JC, González M, De la Cal López MA, Pérez RH, Meneses VS, et al. Clinical practice guide for the management of low cardiac output syndrome in the postoperative period of heart surgery. Med Intensiva. 2012;36:e1-44.

27. Lund BP Gohlke-Bärwolf $C$, Cramariuc $D$, Rossebø AB, Rieck AE, Ger$\mathrm{dts} E$. Effect of obesity on left ventricular mass and systolic function in patients with asymptomatic aortic stenosis (a simvastatin ezetimibe in aortic stenosis [SEAS] substudy. Am J Cardiol. 2010;105:1456-60.

28. Christenson JT, Simonet F, Schmuzinger M. The impact of arterial hypertension on the results of coronary bypass grafting. Thorac Cardiovasc Surg. 1996;44:126-31.

29. Huntley GD, Thaden JJ, Alsidawi S, Michelena HI, Maleszewski JJ, Edwards WD, et al. Comparative study of bicuspid vs. Tricuspid aortic valve stenosis. Eur Heart J Cardiovasc Imaging. 2018;19:3-8.

30. Bleiziffer S, Eichinger WB, Hettich I, Guenzinger R, Ruzicka D, Bauernschmitt $\mathrm{R}$, et al. Prediction of valve prosthesis-patient mismatch prior to aortic valve replacement: which is the best method? Heart. 2007;93:615-20 